\title{
5 Access to Territory under the EU acquis
}

WHICH NORMS ADOPTED within the framework of European integration have a bearing on the ability of protection seekers to gain access to a Member State's territory? As explained earlier, the multitude of existing norms can be divided into two groups. The first group comprises pre-entry measures, and consists of the EU visa acquis as well as norms complementing it. The second group comprises post-entry measures steering the allocation to states within and outside the Union, as well as norms complementing them. Each shall be dealt with in turn below.

\subsection{Pre-entry Measures}

Pre-entry measures affect the possibility of protection seekers to reach the territory of potential host states. Amongst these measures, visa requirements are the prime tool of control. However, to improve their efficiency, states have devised a number of complementary norms, which shall also be dealt with in the present section. They comprise carrier sanctions and measures countering human smuggling as well as prefrontier training and assistance programmes. 


\section{CHAPTER 5}

\subsubsection{The Harmonisation of Visa Regimes}

Visa harmonisation involves formal and material issues. On the material side, the harmonisation of visa requirements operated by single Member States occupies an important position. A further step towards material harmonisation would be to agree on conditions for the issuing of visas. The formal side stretches over procedural and technical co-operation, e.g. modes of sharing information on applicants or the standardisation of visa documents. As we are seized with the impact of visa policies on the seeking of extraterritorial protection, the main focus of this subsection shall be on a particular material aspect, namely the harmonisation of visa requirements. Beyond that, other forms of material co-operation as well as procedural and technical co-ordination shall be covered to the extent they touch upon the position of protection seekers.

Why is it so important to harmonise visa requirements in an area without internal border controls? Let us explain by means of a simple example. A is a citizen of country X. She wishes to go to Germany, where members of her family are staying. For citizens of $\mathrm{X}$, a visa is requested to enter Germany. She applies for a visa at the German embassy in Sarajevo, but her application is turned down. Subsequently, A finds out that Italy does not require a visa from citizens of $\mathrm{X}$. Hence, A goes to Italy. Once there, she takes advantage of the abolition of internal border controls among the Schengen states, and travels on to Germany. In an area without internal border controls, divergences in visa requirements undermine the efficiency of entry control. Therefore, 'the operation by Member States of visa controls on the movement of third-country nationals is, in practical terms, irreconcilable with the complete abolition of border controls' ${ }^{448}$ Compared to a non-Schengen state, for example the U.K., Germany has very limited chances of exercising its personal sovereignty.

How have the Schengen group and the EC approached the problem of diverging regimes? First, the co-operating states agree on which nationalities shall be required to hold an entry visa by all states in an area of free movement. This is the so-called 'negative list'. Second, the cooperating states can also draw up a list of third countries whose citizens are free to enter without a visa. This is the so-called 'positive list'. Beyond both lists, there are states whose nationals are requested to hold an entry

${ }^{448}$ Case C-170/96, Commission of the European Communities $v$ Council of the European Union, Opinion of Advocate General Fennelly, 5 February 1998, para. 19. 
visa by some Member States, but not by others. These residual countries are entered onto the so-called 'grey list'. Eliminating countries from the grey list and moving them over to the negative or the positive list is the goal of harmonisation. An empty grey list is the ultimate desideratum, and it would mean that visa regimes within the area of free movement are fully integrated. Constellations as the one described earlier would be inconceivable then-A could not have entered Italy, which would have blocked her secondary movement to Germany.

This is the status quo of harmonisation on visa lists ${ }^{449}$ : At the time when the Schengen acquis was integrated into the EU framework, its negative visa list embraced 132 entries ${ }^{450}$, and its positive list contained 44 entries. The grey list of the Schengen group comprised only one entry. The EC as a whole has a less demanding negative list, including over 101 entries. ${ }^{451}$ With the entry into force of the Amsterdam Treaty, the EC has received competence for adopting a positive list. ${ }^{452}$ To date, this competence has not been made use of. A comparison of the Schengen acquis with its EU counterpart indicates that harmonisation had proceeded much farther within the Schengen group.

In the EC, the harmonisation of visa requirements is limited to visas for an intended stay of no longer than three months. ${ }^{453}$ The harmonisation mandate under the Schengen Convention goes further, but the focus is also on short-term visas. For intended stays no longer than three months, the Schengen Convention has introduced the so-called Schengen visa, valid in the whole Schengen area.

Focusing on short-term visas means concentrating harmonisation efforts in an area where the latter yield maximum effect. Quite logically, it is generally easier to be granted a short-term rather than a long-term visa. Due to the much larger migratory volumes using them, short-term visas are more vulnerable to irregular behaviour by the immigrant, such as secondary movements or overstaying. Therefore, a harmonisation of

\footnotetext{
449 Source indications are given in the subsequent sections on visa harmonisation in the EU and within the Schengen framework.

450 'The term 'entry' is chosen because it covers recognised states as well as entities not recognised as states by all co-operating states.

451 Of these entries, one relates to an entity not recognised as a state by all the Member States, namely Taiwan.

452 Art. 62 (2) (b) (i) TEC.

453 See Art. 10 (1) SC, Art. 62 (2) (b) TEC and Art. 5 Visa Regulation.
} 


\section{CHAPTER 5}

requirements for short-term visas is a rational entry point for the integration process.

\subsubsection{Visa Harmonisation in the EU}

As mentioned earlier, a persistent split in competencies hampers harmonisation in the EU, involving both the first and the third pillar. The framework for the harmonisation of visa requirements is laid down in the binding and directly applicable ${ }^{454}$

O Council Regulation (EC) No 574/99 of 12 March 1999 determining the third countries whose nationals must be in possession of visas when crossing the external borders of the Member States. ${ }^{455}$

Regulations are the most interventive form of Community law-making: they leave no discretion whatsoever to Member States as to the transposition of norms into domestic legal systems. Within the whole acquis impacting on migration and extraterritorial protection, this is the only regulation on offer, and it is no coincidence that it relates to the prime device of migration control, namely visa requirements.

This instrument defines the term 'visa' as an authorisation given or a decision taken by a Member State, which is required for entry into its territory with a view to:

- an intended stay in that Member State or in several Member States of no more than three months in all;

${ }^{454}$ It is explicitly stated in its Art. 7 that the Visa Regulation 'shall be binding in its entirety and directly applicable in all Member States'.

${ }^{455}$ OJ (1999) L 072, 18/03/1999, pp. 2-5 [hereinafter Visa regulation]. This regulation replaces Council Regulation (EC) No 2317/95 determining the third countries whose nationals must be in possession of visas when crossing the external borders of the Member States, 25 September 1995, OJ (1995) L 234/1. The 1995 Regulation was successfully challenged by the Commission before the ECJ, as the EP had not been consulted. See Parliament vs. Council, European Communities Reports of Cases 1997 I, 3231. 
- transit through the territory of that Member State or several Member States, except for transit through the international zones of airports and transfers between airports in a Member State ${ }^{456}$

Nationals of those third countries on the common list annexed to the Visa Regulation shall be required to be in possession of visas when crossing the external borders of the Member States. ${ }^{457}$ The Visa Regulation excludes the following groups from a common regulation: (1) nationals of states and holders of passports or travel documents issued by non-recognised territorial entity or authority not on the common list and (2) stateless persons and recognised refugees. ${ }^{458}$ The competence to determine visa requirements regarding these groups rests with the Member States, who are obliged to inform the other Member States and the Commission on the measures taken by them. ${ }^{459}$

The Visa Regulation contains a savings clause for 'any further harmonization between individual Member States, going beyond the common list' ${ }^{460}$ This allows members of the Schengen Group to operate a more demanding negative list, without infringing upon their obligations under the Visa Regulation.

Even though a country has been entered on the common list, its nationals may be exempted from visa requirements in specific cases: 'This shall apply in particular to civilian air and sea crew, flight crew and attendants on emergency or rescue flights and other helpers in the event of disaster or accident and holders of diplomatic passports, official duty passports and other official passports. ${ }^{, 461}$ Protection-related reasons are not named in this non-exhaustive enumeration.

From the perspective of the protection seeker, it is relevant to ask what considerations informed the decision to enter a country on the common list. The preamble provides an answer, stating that 'risks relating to

\footnotetext{
456 Art. 5 Visa Regulation.

${ }^{457}$ Art. 1 (1) Visa Regulation. For cases of state succession, Art. 1 (2) prescribes that '[n]ationals of countries formerly part of countries on the common list shall be subject to the requirements of paragraph 1 unless and until the Council decides otherwise under the procedure laid down in the relevant provision of the Treaty'.

${ }^{458}$ Art. 2 Visa Regulation.

459 Art. 2 (4) Visa Regulation.

${ }^{460}$ Art. 6 Visa Regulation.

${ }^{461}$ Art. 4 (1) Visa Regulation.
} 


\section{CHAPTER 5}

security and illegal immigration should be given priority consideration when the said common list is drawn up'. ${ }^{462}$

The exact implications of the term 'risks relating to illegal immigration' remain undefined. However, a look at the common list suggests that those countries producing substantial numbers of protection seekers must have been entered due to the 'risks relating to illegal immigration' connected with them. On the common list, one can find the Federal Republic of Yugoslavia, Iraq and Turkey. Numerically, these three countries top the list of sending countries, representing 42 percent of total asylum applications filed in Europe in $1998 .{ }^{463}$ The same countries also top a list of countries ordered along the number of recognitions in the period 198998 (relating to both Convention refugee status and humanitarian status), surpassed only by Bosnia-Herzegovina. ${ }^{464}$ There can be little doubt that the number of protection seekers impacts on the assessment of 'risks related to illegal immigration' for the purposes of drawing up the common list.

Airport transit has been another open flank for migration control. Consider the following case. $\mathrm{Y}$ wishes to seek asylum in France. Her nationality is subject to French visa requirements. Her application for a French visa is turned down. She books an airline ticket to a destination outside Europe. Her flight connection involves a transit at Paris Charles de Gaulle airport. In the transit zone, she approaches an official of the French border police with an asylum claim. Due to its obligations under Article 33 GC, France has to process the claim.

Thus, for states wishing to control the entry of aliens, airport transit is a very sensitive matter. Certainly, in some jurisdictions, transiting air passengers present in an airport transit zone do not enter the country in a

462 Visa Regulation, preamble, para. (3).

${ }^{463}$ In 1998, the FRY stood for 93836 applications, Iraq accounted for 34521 applications, while the corresponding number for Turkey was 21027 applications. The total number of asylum applications filed that year in Europe was 352404 . The survey draws on statistics from all EU Member States, with the exception of Luxembourg, Portugal and Finland, adding Switzerland, Poland, Norway and Hungary. Source: UNHCR, 1999, p. 78.

464 Iraq: 92267 recognitions, FRY: 74676 recognitions, Turkey: 68854 recognitions. The total of recognitions in the period added up to 730624 . Source: UNHCR, 1999, p. 84. 
technical sense. ${ }^{465}$ However, the transit situation provides an opportunity for filing an asylum claim, which, in turn, may lead to a de jure entry into the territory of the transit state. ${ }^{466}$ Or, as the Council remarks, 'the air route, particularly when it involves applications for entry or de facto entry, in the course of airport transit, represents a significant way in with a view in particular to illegally taking up residence within the territory of the Member States' ${ }^{367}$ For these reasons, the Council has introduced socalled Airport transit visas (ATV). ${ }^{468}$ The vehicle has been a non-binding instrument adopted under the third pillar:

O Joint Action of 4 March 1996, adopted by the Council on the basis of Article K.3 of the EU Treaty, on airport transit arrangements ${ }^{469}$

An actualised version of this instrument is presently being discussed, and would replace the 1996 Joint Action upon adoption:

O Draft Joint Action of the Council on airport transit arrangements, 16 July $1998^{470}$

465 See e.g. Section 59 of the German Aliens Act of 24 February 1997 (BGBl. I p. 310) and Section 18 (a) (3) of the German Asylum Procedures Act. Such solutions do not relieve the state on whose territory the airport is situated from its obligations under human rights law. In Amuur, the ECtHR saw itself competent to consider an alleged deprivation of liberty taking place in the international zone of an airport before entry into French territory in the technical sense. ECtHR, Amuur vs. France, Judgment of 25 June 1996, Reports 1996-III.

466 Compare Section 18a (6) of the German Asylum Procedures Act.

${ }^{467}$ ATV Joint Action, note 469 below, preamble.

${ }^{468}$ The definition of the term 'visa' in Art. 5 of the Visa Regulation explicitly excludes airport transit visas from the scope of the regulation.

${ }^{469}$ OJ (1996) L 63/8 [hereinafter ATV Joint Action]. The Commission requested the ECJ to annul this Joint Action for encroaching upon EC competencies under Art. 100c(1). The Court maintained that it had jurisdiction in the case, and stated that ATV did not concern the crossing of the external borders of the Member States. The application was thus dismissed. Case C-170/96, Commission of the European Communities $v$ Council of the European Union, Judgment of 12 May 1998. For a comment, see A. Oliveira, 'Case C 170/96, Commission of the European Communities v. Council of the European Union, Judgment of 12 May 1998, [1998] ECR I-2763', 36 CMLR 1 (1999).

470 Not published in OJ yet. 


\section{CHAPTER 5}

For the purposes of the ATV Joint Action, an ATV is defined in its Article 1 as 'the authorisation to which nationals of certain third countries are subject, as an exemption to the principle of free transit laid down in Annex 9 to the Chicago Convention on International Civil Aviation, for transit through the international areas of the airports of Member States'. The core of the ATV Joint Action is laid down in Article 3:

Each Member State shall require an airport transit visa of nationals of third countries included on the joint list in Annex I hereto who do not already hold an entry or transit visa for the Member State in question when passing through the international areas of airports situated within its territory.

The list attached as Annex I comprises ten countries ${ }^{411}$ : Afghanistan, Ethiopia, Eritrea, Ghana, Iran, Iraq, Nigeria, Somalia, Sri Lanka and Zaire. The majority of these countries have a poor human rights record ${ }^{472}$ and produce substantial numbers of protection seekers ${ }^{473}$.

An ATV is issued by the consular services of the Member States, who shall determine the conditions of its issue 'subject to adoption by the Council of criteria relating to the preliminaries for and issue of visas'. ${ }^{474}$ Article 2 of the ATV Joint Action underscores specifically that '[i]n all cases, the consular services must ascertain that there is no security risk or risk of illegal immigration'. ${ }^{475}$ This would mean that a consular officer will deny an ATV if she suspects that the transit passage will be used for the purposes of filing a protection claim.

471 The Draft Joint Action currently under discussion adds Bangladesh, the Democratic Republic of the Congo and Pakistan to the list, while Zaire is omitted. It should be noted that Zaire has changed its name to the Democratic Republic of Congo after the successful insurgency of Laurent Kabila.

${ }^{472}$ On the human rights situation, see generally the U.S. Department of State Country Reports on Human Rights Practices 1998, available at < http://www.state.gov/www/ global/human_rights/1998_hrp_report/98hrp_report_toc.html > (accessed on 1 December 1998).

${ }^{473}$ The 1998 statistics for asylum applications filed in Europe indicate that Iraq occupies second place, Afghanistan is fourth, Sri Lanka fifth, Somalia sixth, Iran eighth, and Nigeria fourteenth among the top seventeen countries of origin of asylum seekers. See UNHCR, 1999, p. 82.

${ }^{474}$ ATV Joint Action, Art. 2.

475 See also the preamble of the ATV Joint Action, alluding to 'the objectives of security and control of illegal immigration of the Treaty'. 
It must be underscored that, at present, the ATV Joint Action is binding merely on a political level. So far, the Visa Regulation and the ATV Joint Action remain the only instruments aiming at a material harmonisation in the visa field.

On the procedural aspects of visa harmonisation, the Council has adopted a non-binding

O Council Recommendation of 4 March 1996 relating to local consular cooperation regarding visas ${ }^{476}$

The rationale of this instrument is to curb 'visa shopping'-a practice by which a third country national would seek to augment her chance for obtaining a visa by filing an application with several Member States simultaneously. To counter visa shopping, the quoted instrument recommends a number of measures promoting the co-operation of local consular services.

On the technical aspects of visa harmonisation, a binding instrument has been adopted under the first pillar:

O Council Regulation (EC) No 1683/95 of 29 May 1995, laying down a uniform format for visas ${ }^{477}$

Standardising visa formats facilitates entry control and the detection of false visas. Precisely as procedural harmonisation, such standardisation has an indirect bearing on the interests of protection seekers. For a desperate protection seeker who cannot obtain a visa of a Member State by regular means, visa shopping or the use of false documents may be the only remaining avenue to protection.

\subsubsection{Visa Harmonisation in the Schengen Group}

When it comes to harmonising visa matters, the Schengen Group has outstripped the EU in many respects. The reason is simple: in the Schengen area, internal border control has already been abolished, while this step has not been taken within the EU at large. Abolishment creates a

\footnotetext{
476 OJ (1997) C 80, pp. 23-7.

477 OJ (1995) L 164, pp. 1-4.
} 


\section{CHAPTER 5}

strong pull towards adopting and implementing flanking measures. This becomes particularly clear in the visa area. While both the EU at large and the Schengen Group maintain a negative list, only the Schengen Group has adopted a binding positive list as well. While the ATV list of the EU is only politically binding, the Schengen Group has agreed on a legally binding counterpart. While the EU has launched a non-binding recommendation on consular co-operation, the Schengen Group has elaborated a binding code harmonising all procedural and technical issues connected with the issuing of visas. The benefit for the individual wishing to stay no longer than three months is a uniform Schengen visa, valid not only in the issuing state, but in all states of the Schengen area. There is no equivalent to the uniform Schengen visa in the EU at large.

In the Schengen area, visa issues are regulated exhaustively in two instruments:

o the Schengen Convention, in particular Articles 9-18, and

O the Common Consular Instruction to the Diplomatic Missions and the Consular Posts of the Contracting Parties to the Schengen Convention, which are Headed by Career Consular Officers with its Annexes ${ }^{478}$.

The base for all visa harmonisation within the Schengen Group is contained in Article 9 SC:

1. The Contracting Parties undertake to adopt a common policy on the movement of persons and in particular on the arrangements for visas. They shall give each other assistance to that end. The Contracting Parties undertake to pursue by common agreement the harmonization of their policies on visas.

${ }^{478}$ Gemeinsame Konsularische Instruktion an die diplomatischen Missionen und die Konsularischen Vertretungen der Vertragsstataten des Schengener Durchführungsübereinkommens, die von Berufsbeamten geleitet werden [hereinafter Common Consular Instruction, abbreviated CCI], reprinted in A. Hildebrandt and K. Nanz, Visumpraxis. Voraussetzungen, Zuständigkeiten und Verfabren der Visumerteilung in den Staaten des Schengener Abkommens (1999, Verlag R.S. Schulz, Starnberg), pp. 209-324. A revised version of the CCI was adopted in 1999: Schengen Executive Committee, Decision of the Executive Committee of 28 April 1999 on the definitive versions of the Common Manual and the Common Consular Instructions. Hitherto, none of the named versions has been available in the $\mathrm{OJ}$. 
2. The visa arrangements relating to Third States, the nationals of which are subject to visa arrangements common to all the Contracting Parties at the time when this Convention is signed or later, may be amended only by common agreement of all the Contracting Parties. A Contracting Party may exceptionally derogate from the common visa arrangements with respect to a Third State for over-riding reasons of national policy that require an urgent decision. It must first consult the other Contracting Parties and, in its decision, must take account of their interests and of the consequences of that decision.

It follows that the Schengen co-operation aims at adopting not merely a harmonised, but a common visa policy. Based on this provision, the Schengen Group has drawn up a negative list and a positive list, which are annexed to the CCI. ${ }^{479}$ Both are legally binding. Already in the Schengen Convention, provision is made for a common visa. ATV, transit visas, visas for short term stay, visas for multiple entries and group visas are all subject to common rules, provided that the accumulated stay in the area of the Contracting Parties does not exceed three months. ${ }^{480}$ Visas for longer periods of stay are subject to the discretion of the Member States. ${ }^{481}$

As earlier mentioned, the negative list contains 132 entries, the positive list features 44 entries, while the grey list holds a sole entry. Regarding the issue of airport transit visas, the negative list of the Schengen Group is somewhat more comprehensive than its counterpart in the presently valid ATV Joint Position. The Schengen list contains the following countries: Afghanistan, Bangladesh, Democratic Republic of Congo, Ethiopia, Eritrea, Ghana, Iran, Iraq, Nigeria, Pakistan, Somalia and Sri Lanka. The list laid down in the 1998 Draft ATV Joint Action is actually identical with the Schengen list. Thus, an adoption of the former instrument would imply a further integration of the Schengen acquis into the Union framework. Nonetheless, the Schengen list is legally binding, while a Joint Action is not.

${ }^{479}$ Annex 1 to the CCI contains the negative, the positive and the grey list. These lists have been updated by means of two Schengen Executive Committee Decisions: Decision of the Executive Committee of 15 December 1997 on the harmonisation of visa policy and Decision of the Executive Committee of 16 December 1998 on the abolition of the grey list of States whose nationals are subject to the visa requirement by certain Schengen States.

${ }^{480}$ Arts 10 (1) and 11 SC; CCI, Chapter I, para. 2.1.

481 CCI, Chapter I, para. 2.2. 


\section{CHAPTER 5}

The procedure to be followed when issuing a Schengen visa is regulated in a detailed fashion, and Contracting Parties are bound to follow it. The CCI contain rules on the determination of the responsible state ${ }^{482}$, the procedure to be followed by the claimant when making a request ${ }^{483}$, the processing of that request and decision-making ${ }^{484}$, the administration of visa issues ${ }^{485}$ and the co-operation of local consular posts. ${ }^{486}$

A central element in these procedures is the question of the claimant's true intentions. Is there a risk for defection, once the claimant has reached the Schengen territories? Does she wish to immigrate, rather than to return or travel on after the envisaged short-term stay? The CCI alludes repetitiously to the element of intent. In the admission phase, the credibility of the claimant is looked into: 'The claimant has to convince the consular post seized with the claim that [...] return to the country of origin is warranted' ${ }^{487}$ If doubts persevere, credibility should be furthor investigated in the personal interview with the claimant. ${ }^{488}$ The decisionmaking process is also geared toward the credibility issue. The CCI underscores that one of the essential elements in decision-making is the risk for unauthorised immigration. 'Special attention should be directed at "circles of persons with an increased risk factor" as unemployed persons or persons not possessing regular incomes'. ${ }^{489}$ It should be underscored that the CCI contain no instructions whatsoever for cases where a visa is sought for protection-related grounds.

Contracting Parties-and their consular posts-are bound to issue a Schengen visa only if specified preconditions are fulfilled. According to Article $5 \mathrm{SC}$, a Schengen visa may be issued provided that the applicant fulfils the following conditions:

- she is in possession of a valid document or documents permitting them to cross the border, as determined by the Executive Committee;

\footnotetext{
${ }^{482} \mathrm{CCI}$, Chapter II.

${ }^{483}$ CCI, Chapter III.

${ }^{484} \mathrm{CCI}$, Chapter V.

${ }^{485} \mathrm{CCI}$, Chapter VII.

${ }^{486}$ CCI, Chapter VIII.

${ }^{487}$ CCI, Chapter III, para. 3.

488 CCI, Chapter III, para. 4.

${ }^{489} \mathrm{CCI}$, Chapter V.
} 
O if applicable, she submits documents substantiating the purpose and the conditions of the planned visit and has sufficient means of support, both for the period of the planned visit and to return to their country of origin or to travel in transit in a Third State, into which their admission is guaranteed, or is in a position to acquire such means legally;

O she has not been reported as a person not to be permitted entry; and

O she is not considered to be a threat to public policy, national security or the international relations of any of the Contracting Parties. ${ }^{490}$

How do these conditions link to the right to entry? To start with, the possession of a visa does not entitle the holder to entry. It merely entitles the holder to seek entry or transit at a border post, and the border post may still reject the alien in possession of a visa. ${ }^{491}$ On the other hand, entry to the territories of the Contracting Parties must be refused to any alien who does not fulfil all these conditions and, where required, is in possession of a visa. ${ }^{492}$ Nonetheless, there is an opening for protectionrelated cases in Article 5 (2) SC: where a Contracting Party considers it necessary, it may derogate from that principle on humanitarian grounds or in the national interest or because of international obligations. In such cases permission to enter will be restricted to the territory of the Contracting Party concerned, which must inform the other Contracting Parties accordingly. ${ }^{493}$ Article 15 SC states explicitly that these rules shall not preclude the application of special provisions concerning the right of asylum.

For the three exceptional reasons enumerated in Article 5 (2) SC, a Contracting Party may not only allow entry to its territory, it may also issue a visa. However, in cases where a Contracting Party makes use of its right to exceptional derogation, it shall restrict the validity of the visa

\footnotetext{
490 Art. 5 SC compared to Art. 15 (a), (c), (d) and (e) SC.

491 CCI, para. 2.1.

${ }^{492}$ Art. 15 SC.

${ }^{493}$ Ibid.
} 


\section{CHAPTER 5}

issued to its own territory and inform the other Contracting Parties of its decision. ${ }^{494}$

For protection seekers, the message boils down to the following. Provided that 'international obligations' flowing from refugee law or human rights law enshrine a right to entry or, at least, a right to nonrejection for protection-related grounds, this right shall override the rules of the Schengen Convention. If such obligations can be shown to exist in international law ${ }^{495}$, the Contracting Party concerned must allow entry in such cases. Beyond that, a Contracting Party may allow entry on humanitarian grounds or in the national interest.

\subsubsection{Mainstreaming the Schengen Visa acquis: The Commission Proposal}

The Commission has presented a proposal for a revised visa regulation which draws on the new first pillar competencies made available through the Treaty of Amsterdam as well as reacting to the incorporation of the Schengen acquis into the Union framework. The new regulation would in fact amalgamate the EC Visa Regulation presently in force with parts of the Schengen visa acquis:

O Proposal for a Council Regulation listing the third countries whose nationals must be in possession of visas when crossing the external borders and those whose nationals are exempi from that requirement. ${ }^{496}$

Provided that it is eventually adopted, this instrument would give a telling example of the variable geometry reigning in Title IV. Curiously enough, it could be binding for countries outside the Union (that is, Iceland and

\footnotetext{
${ }^{494}$ Art. 16 SC.

495 See chapters 10.2 and 12.1 on the question of entry.

${ }^{496}$ At the time of writing this document has not been published in the OJ. Henceforth Visa Regulation Proposal.
} 
Norway), without even binding all Member States. ${ }^{497}$ It is based on Article 62 (2) (b) (i) TEC, which endows the Community with competency of drawing up not only a negative list (as it was already empowered to do during the Maastricht era), but also a positive list.

The proposed negative list is brought up to the length of the Schengen visa acquis, adding 34 entries to the list annexed to the 1999 EC Visa Regulation, thus bringing the total up to 134 . Going further than earlier instruments, the proposed positive list suggests the exemption of 48 entries from visa requirements in the Union. This means that Member States are precluded from unilaterally determining visa requirements once the Visa Regulation Proposal is adopted. In other words, the grey list will be relegated to history.

Just as in the existing EC Visa Regulation, Member States are entitled to make a number of exhaustively listed exceptions for nationals otherwise falling under its visa requirements under the proposed Regulation. Nonetheless, the relevant paragraph still makes no mention of protectionrelated grounds. ${ }^{498}$

\subsubsection{Measures Complementing Visa Regimes}

In the preceding section, the current status of visa harmonisation has been expounded at some length. Yet the effectiveness of the visa system would be greatly diminished if aliens could reach international airports or sea ports of the issuing states without a visa. In principle, the border police of the issuing state in the course of passport control could reject them. However, International law may inhibit their forcible return once they have made contact with the territory of a potential host state or they may simply not have the financial means to return. To avoid such situations,

${ }^{497}$ For Ireland and the U.K., the validity of the Regulation would hinge on an opt-in. For Iceland and Norway, validity would presuppose consideration in the Joint Committee set up under the 1999 Agreement between the Council, Iceland and Norway. With regard to Denmark, a division of opinions seems to exist. The Commission considers that the competencies conferred upon the Community by Art. 100c/Maastricht are congruent with that under Art. 62 (2) (b) (i) TEC (see the Explanatory Memorandum attached to the Visa Regulation Proposal). It is unlikely, however, that Member States will accept this interpretation, given that they have opted for an explicit change in the wording of Article 100c/Maastricht.

${ }^{498}$ Art. 5 Visa Regulation Proposal. 


\section{CHAPTER 5}

states have been eager to make the possession of a valid visa a precondition for departure from a third country. Thus, control is externalised and shifted to the pre-departure stage. One method is to make carriers liable for transporting aliens not in possession of a valid visa. By means of such sanctions, carrier are incited to control visas and travel documents before embarkation. Carrier sanctions move the border control of the destination state to the check-in counter at airports in third countries.

Another method of control targets the informal sector offering travel services, the tool being to fine human smugglers. A third method is to send staff or equipment to third countries, which are thus enabled to carry out more efficient departure controls. This method goes by the name of pre-frontier assistance and training. In the absence of these complementary measures, the effectiveness of visa requirements as a means of entry control would be markedly diminished. ${ }^{499}$

\subsubsection{Carrier Sanctions}

Article 26 SC contains an obligation for states to introduce rules on the responsibilities of carriers in their national legislation. This responsibility is preventive and reparative. On the preventive side, carriers 'shall be obliged to take all necessary measures to ensure that an alien carried by air or sea is in possession of the travel documents required for entry into the territory of the Contracting Parties, ${ }^{500}$ On the reparative side, the carrier is tasked with the removal of aliens denied entry:

If an alien is refused entry into the territory of one of the Contracting Parties the carrier which brought him to the external border by air, sea or land shall be obliged to assume responsibility for him again without delay. At the request of the border surveillance authorities the carrier must return the alien to the Third State from which he was transported, to the Third State which issued the travel document on which he travelled or to any other Third State to which he is guaranteed entry. ${ }^{501}$

\footnotetext{
${ }^{499}$ For an overview of the various components in European and U.S. migration control systems, see B. P. Christian, 'Visa Policy, Inspection, and Exit Controls: Transatlantic Perspectives on Migration Management', 14 Georgetown Immigration Law Journal 1 (1999).

500 Art. 26 (1) (b) SC.

501 Art. 26 (1) (a) SC.
} 
The obligation to incorporate these rules on the preventive and reparative responsibilities of carriers is expressly made subject to the obligations flowing from the 1951 Refugee Convention. ${ }^{502}$

To the preventive and the reparative rules, the Schengen Convention adds a punitive rule:

The Contracting Parties undertake, subject to the obligations arising out of their accession to the Geneva Convention of 28 July 1951 relating to the Status of Refugees, as amended by the New York Protocol of 31 January 1967, and in accordance with their constitutional law, to impose penalties on carriers who transport aliens who do not possess the necessary travel documents by air or sea from a Third State to their territories. ${ }^{503}$

Carrier sanctions as a result evolve into a market mechanism: the aggregate costs of reparative and punitive measures exceed the gains carriers make by selling tickets to undocumented travellers. Sanctions therefore incite carriers to check the travel documents of their passengers scrupulously. ${ }^{504}$

Of ten EU Member States included in a 1997 survey, eight had introduced penalisation rules in their domestic legislation. ${ }^{505}$ Another

502 Art. 26 (1) SC.

${ }^{503}$ Art. 26 (2) SC. According to Art. 26 (3) SC, the preventive and punitive rules shall also apply to carriers of groups by coach over international road links, with the exception of border traffic.

${ }^{504}$ UNHCR has observed the detrimental effects of carrier sanctions prescribed in the Schengen Convention at an early stage: 'In symbiotic relation to visa requirements are the documentation review obligations States in effect impose upon carriers. Forcing carriers to verify visas and other travel documentation helps to shift the burden of determining the need for protection to those whose motivation is to avoid monetary penalties on their corporate employer, rather than to provide protection to individuals. In so doing, it contributes to placing this very important responsibility in the hands of those (a) unauthorized to make asylum determinations on behalf of States (b) thoroughly untrained in the nuances and procedures of refugee and asylum principles, and (c) motivated by economic rather than humanitarian considerations. Inquiry into whether the absence of valid documentation may evidence the need for immediate protection of the traveller is never reached. UNHCR believes that the concerns which States attempt to address through carrier sanctions and visas can be better addressed through the careful harmonization of standards of application, treatment and implementation'. UNHCR, Position on Conventions Recently Concluded in Europe (Dublin and Schengen Conventions), Geneva, 16 August 1991.

505 IGCARMP, 1997, p. 434. 


\section{CHAPTER 5}

source describes the level of co-ordination between Member States as low, and points out that Finland, Spain and Sweden merely oblige carries to take financial and practical responsibility for repatriation. ${ }^{506}$ The German legislation attempts to alleviate the negative effects of carrier sanctions by exempting carries from sanctions where undocumented protection seekers have been accorded some form of protective status. ${ }^{507}$ It goes without saying that such patchwork benevolence cannot halt the market dynamics imposed by the sanctions instrument. After all, airlines and other carriers pursue the interests of their shareholders, and not those of protection seekers. A look at recognition rates would suggest to airlines that transporting protection seekers without documents is too high a risk and therefore, bad business.

\subsubsection{Sanctions against Human Smugglers}

Article 27 (1) SC contains an obligation for Contracting Parties 'to impose appropriate penalties on any person who, for purposes of gain, assists or tries to assist an alien to enter or reside within the territory of one of the Contracting Parties contrary to the laws of that Contracting Party on the entry and residence of aliens'.

Of ten EU Member States screened in a 1997 Survey, six had penalised human smuggling, one had not, and three did not make information available. Penalties ranged from a fine to eight years' imprisonment. ${ }^{508}$

506 European Parliament, 2000, p. 15.

${ }^{507}$ F. Löper, 'Das Dubliner Übereinkommen über die Zuständigkeit für Asylverfahren', 20 ZAR 1 (2000), p. 54. Löper names a corresponding construction in French law and practice, whereby carriers only fined if claimants are entered on a black list, or if protection claims are dismissed by the French authorities as manifestly unfounded. Thus, following the logic of the German and French solutions, a rational, profit-minded airline would need to carry out a small-scale determination procedure at the check-in counter to assess whether transport would entail a gain or a loss. This is manifestly absurd: for the airline, it would entail transactional costs consuming the eventual gains of transporting undocumented protection seekers.

${ }^{508}$ IGCARMP, 1997, p. 434. 


\subsubsection{Pre-frontier Assistance and Training}

Both the EU acquis and the Schengen acquis contain instruments on prefrontier assistance and training. A non-binding instrument adopted by the EU Council has provided an organisational framework for common measures in this field, adding to the bilateral exchanges among Member States and third countries. The relevant instrument is the

- Joint Position of 25 October 1996 defined by the Council on the basis of Article K.3 (2) (a) of the Treaty on European Union, on pre-frontier assistance and training assignments. ${ }^{509}$

This instrument aims to render the control of travel documents and visas prior to embarkation on flights destined for Member States more effective. Assistance assignments have as their objective the provision of assistance to officers locally responsible for checks either on behalf of the local authorities or on behalf of the airlines. ${ }^{510}$ The purpose of joint training assignments shall be among other things to describe Member States' document and visa requirements and the methods by which the validity of documents and visas may be checked. ${ }^{511}$ Joint assistance or training assignments are carried out by specialist officers designated by the Member States. ${ }^{512}$ Where costs are not covered by the relevant third country or the airline involved, they are borne by the Member States agreeing to participate in the implementation of an assistance or training assignment. ${ }^{513}$

Within the Schengen Group, parallel measures have been taken. In a 1998 Decision $^{514}$, the Executive Committee affirms that the Schengen states 'find it necessary' to post 'liaison officers from the Schengen States to countries of origin and the transit countries' whose task would be to advise on the 'preventing of illegal migration [...] so as to fight against

\footnotetext{
509 OJ (1996) L 281/1 [hereinafter Pre-frontier Joint Position].

510 Art. 1 (2) of the Pre-frontier Joint Position.

511 Art. 2 (2) of the Pre-frontier Joint Position.

512 Art. 3 (1) of the Pre-frontier Joint Position.

513 Art. 3 (3) of the Pre-frontier Joint Position.

514 Schengen Executive Committee, Decision of the Executive Committee of 27 October 1998 on the adoption of measures to fight illegal immigration, 27 October 1998.
} 


\section{CHAPTER 5}

illegal immigration into a Schengen State' ${ }^{515}$ This initiative has been pursued further by means of the

O Decision of the Executive Committee of 16 December 1998 on coordinated deployment of document advisers. ${ }^{516}$

Under this instrument, Schengen states are intended to second executive staff as document advisers, whose task is to assist airlines or shipping companies, consular representations of Schengen states in third countries, and border or immigration authorities at airports or seaports of departure in third countries. ${ }^{517}$ Assistance is delivered in the form of training on counterfeited and falsified documents as wells as controls in pre-boarding checks at airports and ports of exit. ${ }^{518}$

The instrument lists 46 locations in 35 countries as suitable postings for document advisers, and assigns them to single Schengen countries. Among these 35 countries, we find the worldwide elite of refugee-producing countries. Two locations in Turkey are pointed out, and one of them is assigned a priority status (Istanbul). In the year the Decision was adopted, Turkey held second place on the list of countries whose nationals are recognised as refugees under the 1951 Refugee Convention in Europe. ${ }^{519}$ Of the 22 top refugee-producing countries of origin listed in the UNHCR 1998 statistics, six are represented on the list of locations: Democratic Republic of Congo, Pakistan, Sri Lanka, Tunisia, Turkey and Vietnam. ${ }^{520}$

It would be of the utmost interest to discover how 'document advisers' and EU training staff are instructed to react to protection-related cases. The instruments themselves do not give explicit instructions on this point, and thus there is the impending risk that individuals in such cases are regarded simply as undocumented migrants to be filtered out. But apart from amplifying the risks of delivering individuals to persecution, the instruments presented in this section evoke unhappy memories of the past. Just like the deployment of military advisers in the decades before the fall of the Iron Curtain, posting document advisers is a strong signifier

\footnotetext{
${ }^{515}$ Ibid., para. 3.

${ }^{516}$ Henceforth Document Adviser Decision. This decision has not been published in the OJ.

517 Para 1 (a) of the Implementation Principles attached to the Document Adviser Decision.

${ }^{518}$ Ibid.

519 UNHCR, 1999, p. 79.

${ }^{520}$ Ibid.
} 
that the burden of conducting the Cold War against protection-induced and other migration is stealthily but inexorably being shifted to third countries.

\subsubsection{Conclusion}

The speedy harmonisation of visa requirements and the increasing coordination of measures complementing them are probably the clearest indicator that internal free movement is to be bought at the price of intensified control. The proliferation of visa requirements is probably the most serious threat to the personal mobility that a person needs in order to seek refuge. ${ }^{521}$ It is important to recall, however, that the issuing of visas on protection-related grounds does not run counter to the visa regimes adopted within the EU or the Schengen Group. Nonetheless, the risk prevails that the consular officer equates the invocation of protectionrelated grounds by the visa claimant with the intent to immigrate in an unauthorised manner. Therefore, in practice, the filter function of visa requirements ultimately hinges on the existence of express domestic rules on the issuance of visas in protection-related cases. Some, but not all, Member States have made provisions for asylum applications at their consular posts and instructed them accordingly. ${ }^{522}$ Others, however,

${ }^{521}$ Christian, 1999, p. 234.

522 In Denmark, such applications fall under section 7 (4) of the Aliens Act. In 1994, 1995 and 1996, 1341,4951 and 1498 persons respectively applied for asylum at a Danish consular post. In the three named years, 90,41 and 17 applications respectively were approved. In France, embassies have been entitled to grant a residence permit to enable the claimant to seek asylum on French territory. The Netherlands accepts asylum requests filed with the Dutch Embassy in the claimant's country of origin. A positive decision entails the issuance of an entry visa. In Spain, the only asylum requests accepted by embassies are those in which the claimant has already left the country of origin. The U.K. accepts asylum claims at its embassies abroad. Belgium, Finland, Germany, Italy and Sweden do not accept asylum claims to be filed at consular posts. Source: IGCARMP, 1997, p. 435. In Austria, Section 12 (2) of the Asylum Law enables aliens to apply for asylum with Austrian diplomatic missions abroad. Greece and Luxembourg do not accept asylum applications to be filed with consular posts. Source: F. Liebaut and J. Hughes, Legal and Social Conditions for Asylum Seekers and Refugees in Western European Countries (1997, Danish Refugee Council, Copenhagen), p. 16. Data for Ireland and Portugal were unavailable. 


\section{CHAPTER 5}

expressly discourage their consular authorities from issuing visas if there are indications of persecution, as this aggravates the risk of 'defection'. ${ }^{523}$

The extent to which international law obliges states to grant entry on protection-related grounds remains an unanswered question. Where such a right can be shown to exist, it could subsequently entail a duty to issue a visa to the beneficiary. This question shall be pursued in a later chapter. ${ }^{54}$

\subsection{Post-entry Measures: The Concept of Safe Third Countries}

In Western Europe, domestic rules for granting asylum vary greatly. This has two consequences. First, a rational protection seeker would not seek protection in just any potential host country, but rather in one having higher recognition rates than others. In other words, a rational protection seeker would prefer to choose between potential host countries. Secondly, it is also perfectly rational for a rejected protection seeker to file a new application in another European country, as chances are fair that the latter will assess her case differently than the country which rejected her. This phenomenon has become by the pejorative label 'asylum shopping'. However, it is important to recall that the behaviour of the protection seeker is not based on a malicious intent to manipulate, but is instead a

523 The information on country-related visa practice provided by the Swedish Statens Invandrarverk [State Immigration Board] is indicative in this regard. With regard to Cuba, it is suggested that a visa should be denied where the claimant 'has problems of a political nature'. With regard to Bulgaria, the occurrence of 'discrimination, mainly of gypsies' is pointed to, so 'a certain caution' should be exercised when processing visa claims from members of this group. For Iraqis, the 'risk of defection' is said to be very high, so it is 'very difficult for Iraqis to make credible' that they solely intend to visit Sweden. Statens Invandrarverk, Region mitt, Visumenheten, Information angående viseringsärenden, 21 October 1999 and 12 November 1999, Doc. No. SIV 19-99-4115, with attachments Praxisinformation Bulgarien, Praxisinformation Kuba, and Praxisinformation Irak.

It is quite noteworthy that for 'prominent politicians or journalists, who risk to be exposed to threats or violence in their professional activity and who wish to "take a rest" outside Algeria for a limited duration, there is no impediment for granting a visa'. Ibid., Praxisinformation Algeriet. From a universalist position, it is certainly to be welcomed that strict visa rules are somewhat relaxed for specific groups. However, it gives rise to concern that the beneficiaries of such relaxations happen to be social elites.

${ }^{524}$ See chapter 12.1 below. 
rational reaction to the disharmony of European protection systems. ${ }^{525} \mathrm{It}$ is a form of market-adapted behaviour that is otherwise praised in Western economies.

Naturally, repeated evaluation of the same case in different European states is a waste of resources. It also renders the interpretation of statistics more difficult, as one person could be behind a number of applications submitted in different states. ${ }^{526}$

Theoretically, two remedies offer themselves-modifying the market offer or closing down the market. The first remedy would consist in slashing the incentive to choose by harmonising the protection offer: if all European states offered roughly the same procedural and material standards, asylum shopping would not make much sense anymore. ${ }^{527}$ Invariably, this process would take time. To be effective, it would also imply deep intrusions into the aliens and asylum legislation of Member States, which are on the whole jealously guarded as belonging to the latter's sovereignty.

The solution actually devised by single Member States resembles a procedural fix rather than a material cure. Instead of intensifying the harmonisation of protection systems, whose divergence was the very cause of secondary movements, states stipulated the fictive equality of these systems, and allocated protection seekers to them under a mechanical rule. The mechanical rule is based on the concept of safe third countries: where a number of formal criteria indicate that the protection seeker could have sought protection in a third country through which she passed, her claim shall be rejected, and she shall be asked to turn to that

525 This is explicitly acknowledged by the European Commission: 'Substantive asylum law and asylum procedures have not yet been approximated and the recognition rates for certain nationalities can vary significantly from one Member State to another, so it is understandable that people in need of international protection may find one Member State a more attractive destination than another'. European Commission, Commission staff working paper. Revisiting the Dublin Convention: developing Community legislation for determining which Member State is responsible for considering an application for asylum submitted in one of the Member States, SEC (2000) 522, 21 March 2000 [henceforth Dublin Working Paper], para. 30.

526 All restrictive measures notwithstanding, it is still unclear to what extent the statistics of applications mirror the actual number of protection seekers, or merely their mobility between European host states.

${ }^{527}$ However, making multiple applications still retains the advantage of delaying removal to the country of origin. 


\section{CHAPTER 5}

country. ${ }^{528}$ Denmark was among the first countries to introduce the safe third concept in its domestic legislation-the so-called Danish clause. ${ }^{529}$ The idea underlying the Danish clause proliferated quickly and found its way into the Dublin and Schengen Conventions, albeit in a more sophisticated form. A crude version of it underpinned a number of bilateral readmission agreements between EC Member States and their European neighbours.

Essentially, the safe third country concept embraces two elements. First, responsibility for the processing of a given protection claim must be established by a set of allocation criteria. Second, the physical readmission of the protection seeker to the responsible country must be secured. As states are under no obligation to readmit non-nationals under customary international law, the readmission obligation must be created by way of treaty. The Dublin Convention joins both elements in one instrument. By contrast, allocation to states outside the Union is usually governed by a readmission agreement only, while the allocation criteria are laid down in domestic law and, to a certain extent, in Union law.

The safe third country concept denies the protection seeker the opportunity to choose among potential host countries and does away with a state obligation to process each claim in substance. ${ }^{530}$ Rather, the host country responsible for processing her claim is determined by the travel route or other allocation criteria. In theory, the market of protection offers has been abolished and replaced by a market of ever more efficient border control. In practice, however, allocation under the safe third country concept will only work if a number of preconditions are fulfilled. The identity and the travel route of the protection seeker have to be established, and the third country must be willing to take over the protection seeker and her case. Establishing the protection seeker's

${ }^{528}$ See R. Byrne and A. Shacknove, 'The Safe Country Notion in European Asylum Law', 9 Harvard Human Rights Journal (1996), p. 186.

529 This radically formalistic solution had been launched by the Danish legislature in 1986. By virtue of the Danish clause, asylum seekers could be sent back to safe third countries regardless of appeal. The circle of safe third countries was determined by administrative practice.

${ }^{530}$ For a good overview of the debate on both issues, see K. Landgren, Deflecting International Protection by Treaty: Bilateral and Multilateral Accords on Extradition, Readmission and the Inadmissibility of Asylum Requests (1999, UNHCR, Geneva), pp. 22-9. On the issue of choice, see also N. Albuquerque Abell, 'The Compatibility of Readmission Agreements with the 1951 Convention relating to the Status of Refugees', 11 IJRL 1 (1999), pp. 75-80. 
identity is necessary in order to inhibit multiple applications under the disguise of false names. Establishing the travel route is mandatory for identifying a relevant third country to which she can be sent back. With these necessities in mind, states have devised methods of information exchange and fingerprinting to meet both threats against the workability of the safe third country concept. To ensure the willingness of third countries to take over protection seekers and their cases, international agreements have been concluded. All of the measures described complement the safe third country concept.

In the following, we shall first look into allocation to other Member States under the Dublin Convention, including the complementary measures linked to it. In a second step, allocation to safe third countries outside the Union will be expounded together with the complementary device of readmission agreements.

\subsubsection{Allocation to other Member States}

\subsubsection{The Dublin Convention}

Allocation among Member States is regulated in a comprehensive and legally binding manner by the Dublin Convention:

- Convention Determining the State Responsible for Examining Applications for Asylum Lodged in One of the Member States of the European Communities ${ }^{531}$

The rationale of the Dublin Convention is twofold. First, it allocates responsibility for the examination of asylum applications lodged on the territory of a Member State and, second, it lays down readmission obligations incumbent on the responsible Member State. Among the goals

53115 June 1990, OJ (1997) C 254, 19 August 1997, pp. 1-12. For a background on the Dublin Convention, see Guild and Niessen, 1996, at 112 et seq. See also J. van der Klaauw, 'The Dublin Convention, the Schengen asylum chapter and the treatment of asylum applications', in P. R. Giuseppin and W. M. Jansen (eds), Het Akkoord van Schengen en vreemdelingen. Eeen ongecontroleerde grens tussen recht en beleid? (1997b); K. Hailbronner and C. Thiery, 'Schengen II und Dublin-Der zuständige Asylstaat in Europa', 17 ZAR 2 (1997). For a description from the perspective of a German government official, see Löper, 2000. 


\section{CHAPTER 5}

of the Convention, the preamble names a desire to speed up procedures, to guarantee a material determination to claimants in one of the Member States and to avoid orbit situations, where claimants are sent back and forth between Member States unwilling to consider their case. ${ }^{532}$ The idea behind the Dublin Convention can be described as 'one for all'. One, and only one, Member State conducts a determination procedure, and it does so on behalf of all other Member States. At least in theory, the Dublin Convention should do away with the much-detested phenomenon of asylum shopping.

The Dublin Convention provides for its own institutional framework. Under its Article 18, a committee has been established consisting of one representative of each Contracting Party as well as a representative of the European Commission. ${ }^{533}$ Among the tasks of the so-called Article 18Committee, we find the examination of 'any question of a general nature concerning the application or interpretation of this Convention'. ${ }^{534}$ Where a Contracting Party experiences major difficulties as a result of substantial change of circumstances since the conclusion of the Dublin Convention, it may bring the matter before the Committee, which can ultimately decide on the suspension of the Dublin Convention for that state. ${ }^{535}$ In deviation from the otherwise prevailing unanimity rule, decisions of suspension under this clausula rebus sic stantibus are taken by two-thirds majority in the Article 18-Committee. ${ }^{536}$

532 Preamble of the Dublin Convention, para. 4. Orbiting refugees were a considerable protection problem during the seventies and eighties. See G. Melander, Refugees in Orbit (1978, International University Exchange Fund, Geneva). For an early analysis of the incapacity of the Dublin Convention to solve the problem of orbiting, see J. J. Bolten, 'From Schengen to Dublin: The New Frontiers of Refugee Law', in J. M. Steenbergen, Schengen. Internationalisation of Central Chapters of the Law on Aliens, Refugees, Privacy, Security and the Police (1992, Stichting NJCM-Boekerij, Leiden), pp. 18-28. Today, with the benefit of statistical hindsight, we may state that Dublin has cloaked the phenomenon of orbiting in new garb. Grahl Miadsen is right to seek the underlying cause for the orbiting phenomenon in the differences between domestic legal systems-a cause still existing in the EU. A. Grahl Madsen, Territorial Asylum (1980, Almqvist \& Wiksell, Stockholm), p. 95.

533 Art. 18 (1) DC. The Commission representative is only entitled to take part in discussions, without being involved in the decision-making process.

534 Art. 18 (2) DC.

535 Art. 17 (2) DC.

536 Art. 18 (3) DC. 
The Article 18-Committee has adopted a number of instruments to facilitate the implementation and application of the Dublin Convention:

O Decision 1/97 of 9 September 1997 concerning provisions for the implementation of the Dublin Convention ${ }^{537}$,

- Decision 2/97 of 9 September 1997 establishing the Rules of Procedure of the Committee set up by Article 18 of the Dublin Convention $^{538}$, and

○ Decision $1 / 98$ of 19 June 1998 of the Article 18 Committee of the Dublin Convention, concerning provisions for the implementation of the Convention ${ }^{539}$.

On the basis of concerns about inefficiencies in the application of the Dublin Convention, the Article 18-Committee also adopted a Programme of Action in June $1998 .{ }^{540}$

Moreover, the implementation of the Dublin Convention has also attracted the interest of the Council, which adopted the

- Council Conclusions of 27 May 1997 concerning the practical implementation of the Dublin Convention. ${ }^{541}$

In spite of these attempts to create greater clarity in the sometimes rather cryptic norms of the Dublin Convention, numerous ambiguities in its interpretation and application remain. Such problems encompass various areas, ranging from divergent readings of the responsibility criteria to requirements of proof. ${ }^{542}$

Regarding the territorial applicability of the Dublin Convention, we recall that Iceland and Norway have become involved with the Schengen co-operation aiming at an area without internal border control. Therefore, these countries must be involved in the system established under the

\footnotetext{
537 OJ (1997) L 281, pp. 1-25.

538 OJ (1997) L 291, p. 26.

539 OJ (1998) L 196, p. 49.

540 Not published in OJ. See Dublin Working Paper, para. 12.

541 OJ (1997) C 191, pp. 27-8. This instrument is not included in the acquis list.

${ }^{542}$ For a good overview, taking into account the divergent positions among Member States, see Löper, 2000.
} 


\section{CHAPTER 5}

Dublin Convention. As the Dublin Convention can only be signed or acceded to by Member States ${ }^{543}$, however, an alternative route has to be used. It is planned that the Commission shall negotiate with Iceland and Norway an agreement aimed at extending to these two countries the rules applied by the EU Member States under the Dublin Convention. ${ }^{544}$

How, then, are the two goals of the Dublin Conventionestablishment of responsibility and readmission obligations-pursued? Let us look at the issue of responsibility first. The Member State responsible for processing an asylum application is established by means of the following responsibility criteria, listed in order of priority:

1. Family: If the applicant's spouse or child under 18 has been recognised as a refugee under the 1951 Refugee Convention by a Member State, and is legally present in its territory, that State shall be responsible for the application, provided the applicant so desires. ${ }^{545}$ As the concept of family is a very narrow one, and the group of recognised Convention refugees is limited ${ }^{546}$, this criterion has only a minor numerical impact in practice.

2. Residence and entry permits: If the applicant has been issued a valid residence permit or a valid visa, the issuing State shall be responsible for the application. This criterion offers a detailed set-up of collision norms for cases where permits have been issued by more than one Member State, including cases where permits have expired. ${ }^{547}$

3. Illegal entry: If the applicant arrived irregularly from outside the Union, the Member State through which she first entered the territory of the Member States shall be responsible for the application. ${ }^{548}$

4. Controlled entry: The Member State responsible for controlling the entry of the applicant into the territory of the Member States will be responsible for examining the application for asylum. An exception is

\footnotetext{
543 Art. 21 (1) DC.

${ }^{544}$ See text accompanying note 425 above.

545 Art. 4 DC.

546 In 1998, this group consisted of 31248 persons in Europe, which must be contrasted to a total of 352404 asylum applications. See UNHCR, 1999.

547 Art. 5 DC.

548 Art. 6 DC.
} 
made for cases where the applicant first entered a Member State where the visa obligation is waived, before presenting an application for asylum in another Member State where the visa obligation is also waived. In this case, the latter State shall be responsible for examining the application for asylum. ${ }^{549}$ Thus, this criterion only applies if there is a differential visa policy between two Member States-a phenomenon which visa harmonisation will eventually put an end to.

5. State in which the application was first lodged: If no other contracting State can be made out, the first Member State in which the applicant has lodged her application shall be responsible for it. ${ }^{550}$

It should be stressed that the responsibility criteria only relate to asylum applications-that is, according to the definition spelt out in Article 1 (1) (b) DC, applications for protection under the 1951 Refugee Convention. Therefore, we have to speak of asylum seekers, and not of protection seekers, when alluding to the personal scope of the Dublin Convention in the following. ${ }^{51}$

The first four criteria send out a very clear message to Member States. In general terms, refugee recognition, the granting of visas and residence permits, liberal visa requirement policies and lax controls of external borders may lead to responsibility. The essence of these criteria can be expressed as follows: that state initially causing the presence of an asylum seeker on the territories of Member States shall bear the responsibility for her. Even the fifth criterion falls in line with this message: the Member State in which an applicant has lodged her first claim in Union territory shall see to it that this applicant does not embark on secondary movements. If she does, responsibility under the Dublin Convention will not move with her, but shall rest with the first state. The practical effects of this criterion are illustrated by the case of Bosnian protection seekers in Germany. Faced with the expiry of their toleration permits and the

549 Art. 7 DC.

550 Art. 8 DC.

551 This confinement to persons seeking protection under the 1951 Refugee Convention entails two problems. First Member States disagree as to whether the Dublin Convention also regulates the readmission of recognised refugees. Secondly, as the importance of other forms of protection categories increases, it is unsatisfactory that the Dublin Convention only regulates the allocation of responsibility for a single category. See Dublin Working Paper, paras 47-50. 


\title{
CHAPTER 5
}

implementation of return policies, some of the Bosnians moved on to other Member States-which had not yet embarked on return-to seek asylum there. Due to the fifth criterion, the formal responsibility for processing their claims rested with Germany.

However, the Dublin Convention provides for an opt-out clause, allowing a state to assume responsibility for a case filed on its territory, although it is not obliged to do so under the four criteria:

\begin{abstract}
Each Member State shall have the right to examine an application for asylum submitted to it by an alien, even if such examination is not its responsibility under the criteria defined in this Convention, provided that the applicant for asylum agrees thereto. The Member State responsible under the above criteria is then relieved of its obligations, which are transferred to the Member State which expressed the wish to examine the application. The latter State shall inform the Member State responsible under the said criteria if the application has been referred to it. ${ }^{552}$
\end{abstract}

This clause is usually referred to as the 'sovereignty clause'. It can be used either to the benefit or to the detriment of an asylum seeker. It is beneficial when a Member State uses the sovereignty clause to preserve family unity beyond the narrow confines of the first criterion. It is also beneficial when the state using the sovereignty clause maintains a more liberal recognition practice than the state to which allocation would have taken place under the Dublin criteria. This simple equation can be turned around, however. The sovereignty clause has detrimental effects for the asylum seeker when the state invoking it maintains a more restrictive practice than the state to which allocation would have taken place under the Dublin criteria. In certain cases, Germany has used Article 3 (4) DC to achieve rejections and effectuate return to the country of origin rather than feeding the case into the Dublin system. ${ }^{553}$ To be sure, Article 3 (4) $\mathrm{DC}$ requires that the asylum seeker give her consent to an opt-out from

\footnotetext{
552 Art. 3 (4) DC.

${ }^{553} \mathrm{~J}$. van der Klaauw, 'Refugee protection in Western Europe: A UNHCR perspective', in J. Y. Carlier and D. Vanheule (eds), Europe and Refugees - A Challenge? (1997a, Kluwer Law International, The Hague), pp. 235-6, giving examples from the period preceding the entry into force of the Dublin Convention, where allocation was governed by Chapter VII SC. The analogy is valid, as the content of Chapter VII SC is almost identical to the content of the Dublin Convention.
} 
the criteria. In the case of Germany, the authorities opined that this consent had implicitly been given when the asylum application was filed with German authorities. ${ }^{554}$

We recall that the Dublin Convention is based on a fictive equality of divergent domestic asylum systems. All too easily, a Member State might see itself confronted with the following situation. If a protection claim were examined in substance by its own authorities, the claimant would be allowed to stay due to the prohibition of refoulement. If, however, the Dublin criteria were to be applied, the claimant would be allocated to another Member State with a more restrictive practice, which would reject her and effectuate return. The conflict is obvious: deviating from the Dublin criteria implies the risk of undermining the Dublin Convention; at the same time, adhering to its criteria means accepting chain refoulement, which would be at odds not only with Article 33 GC, but also with Article 2 DC:

The Member States reaffirm their obligations under the Geneva Convention, as amended by the New York Protocol, with no geographic restriction of the scope of these instruments, and their commitment to co-operating with the services of the United Nations High Commissioner for Refugees in applying these instruments.

In such situations, the sovereignty clause could be used to avert an outright conflict between Geneva and Dublin.

The sovereignty clause in Article 3 (4) DC is complemented by Article $9 \mathrm{DC}$, which allows states other than those receiving the application to volunteer for processing the case. This norm is usually referred to as the 'humanitarian clause':

Any Member State, even when it is not responsible under the criteria laid out in this Convention, may, for humanitarian reasons, based in particular on family or cultural grounds, examine an application for asylum at the request of another Member State, provided that the applicant so desires. If the Member State thus approached accedes to the request, responsibility for examining the application shall be transferred to it. ${ }^{555}$

${ }^{554}$ Ibid.

555 Art. 9 DC. Compare also Art. 3 (4) DC. 


\section{CHAPTER 5}

What does responsibility under the Dublin Convention entail? According to Article 10 (1) DC, the Member State responsible for examining an application for asylum according to the named criteria shall be obliged to:

O take charge of an applicant who has lodged an application for asylum in a different Member State;

O complete the examination of the application for asylum;

o readmit or take back an applicant whose application is under examination and who is irregularly in another Member State;

○ take back an applicant who has withdrawn the application under examination and lodged an application in another Member State; and

O take back an alien whose application it has rejected and who is illegally in another Member State.

The responsibility to readmit and to take back encourages Member States to prevent secondary movements and to effectuate the speedy removal of rejected asylum seekers from their territory to the country of origin.

Let us give a brief description of how an asylum claim will be handled by a Member State, taking into account the allocation mechanism set out in the Dublin Convention.

1. An asylum seeker files an asylum application with a contracting State.

2. The contracting State receiving the application assesses whether there is any third State to which it wishes to return the asylum seeker according to its national legislation. ${ }^{556}$

3. The State responsible for the application will be determined by the contracting States along the lines of the criteria given in the Dublin Convention.

4. The asylum seeker and her application are taken charge of by the responsible State.

556 Art. 3 (5) DC. Paragraph 3 (a) of the Resolution on a harmonised approach to questions concerning host third countries gives prevalence to return to a host third country before considering return to a Member State, 30 Nov./1 Dec. 1992, Doc. No. SN 4823/92. See Guild and Niessen, 1996, pp. 121-2. 
5. The responsible State carries out an individual determination procedure.

The order of priority is clear: first and foremost, the asylum seeker should be allocated to a country outside the Union. Only where this is not feasible, allocation under the Dublin Convention is considered. This runs counter to the intention, stated in the preamble, to ensure that one of the Member States will examine a protection claim on its merits. Referral to a non-Member State implies the opposite: no material examination shall take place by any of the Member States. Thus, allocation under the Dublin Convention is not a closed, self-contained mechanism with a predictable outcome. After all, Member States have different legal and factual preconditions for allocating asylum seekers to states outside the Union. Domestic legislation on safe third countries varies ${ }^{557}$, as does the availability of workable readmission arrangements with third states.

The Dublin Convention has been exposed to massive criticism from the moment of its inception, most of it emanating from a universalist and protection-minded perspective. ${ }^{558}$ However, even governments of Member States have voiced concerns about the ineffective functioning of the Convention. Therefore, it is no surprise that Member States assigned themselves to reconsider the suitability of the rules laid down in the Dublin Convention in the next years. By 2004, the EC shall have adopted a measure on the very issue regulated today by the Dublin Convention. We recall that Article 63 (1) (a) TEC obliges the EC to adopt, within a period of five years after the entry into force of the Treaty of Amsterdam, 'criteria and mechanisms for determining which Member State is responsible for considering an application for asylum submitted by a national of a third country in one of the Member States'.

Following the non-binding Action Plan on the Implementation of the Amsterdam Treaty, a 'continued examination of the criteria and conditions for improving the implementation of the Convention and of the possible transformation of the legal basis to the system of Amsterdam ${ }^{\text {,59 }}$

557 See Council of the European Union, Monitoring the implementation of instruments adopted concerning asylum-Summary report of the Member States' replies to the questionnaire launched in 1997, 17 July 1998, Doc. No. 8886/98, ASIM 139, pp. 23-31.

${ }_{558}$ For an outright rejection, see Bolten, 1992.

559 Action Plan, para. 36 (b) (i). 


\section{CHAPTER 5}

should take place within two years after the entry into force of the Amsterdam Treaty, shortening the period set out in Article 63 TEC.

In early 2000, the Commission drew up a detailed working paper on the Dublin Convention and its replacement by a Community measure, which elaborates on the goals pursued by the Dublin Convention and attempts to identify whether the content and implementation of the Convention lives up to them. ${ }^{560}$ The Dublin Working Paper reflects some of the criticism voiced against the Convention. In the following, we shall summarise pivotal elements of this criticism.

\section{Long processing delays}

One of the goals of the Convention was to avoid orbit situations, where asylum seekers are left in doubt for too long as regards the likely outcome of their applications or where they are referred successively from one Member State to another without any of these States acknowledging itself to be competent to examine their application. It is quite obvious that this goal is far from being reached. The Commission states that the average time for processing Dublin cases exceeds the target of one month set out in Article 4 (1) of Decision 1/97. For some Member States the average delay is as much as 90 days, which is the maximum allowed under Article 11(4) DC, before the state to which the request was made is automatically deemed to have accepted responsibility. The Commission notes further that the Convention itself sets generous time limits: where all margins are made full use of, the time-span from individual application to transfer to the responsible Member State may take up to nine months. Such long delays cause great insecurity for the asylum seeker and approximate the limbo of the very orbit situations that the Convention was originally set to solve. ${ }^{561}$ Paradoxically, the Dublin process may consume more time than a substantial determination procedure would have done, thus harming protection and control interests alike. 'During the process, it is

${ }^{560}$ Dublin Working Paper. See note 525 above.

${ }^{561}$ Dublin Working Paper, paras 14-20. 
not practicable to keep the asylum seeker detained' states one U.K. official, admitting that 'it is often very difficult to keep track' of her. ${ }^{562}$

\section{Low efficiency of allocation mechanism}

Another goal was to prevent asylum applicants from being able to pursue multiple asylum applications, either concurrently or consecutively, in different Member States and thus to deny asylum seekers the possibility of choosing among Member States. Here, the Commission cautiously indicates that the efficiency of the Dublin system cannot presently be assessed due to the lack of statistics, but spells out some hope for improvement if and when the Eurodac system will have become fully operational. ${ }^{563}$ The incomplete statistics currently available suggest that some four percent of all asylum applicants are transferred between Member States under the Dublin Convention. ${ }^{564}$ The U.K. official quoted earlier suggests that ' $[\mathrm{t}]$ he reality is that, at present, most asylum seekers can effectively choose their country of asylum within the EU' ${ }^{565}$

The reasons for the limited efficiency of the allocation mechanism are primarily to be sought in the difficulties of gathering sufficient evidence relating to the responsibility criteria. ${ }^{566}$ Referring to U.K. case law, the Commission also takes note of the fact that referrals are also inhibited by the divergent interpretations of the 1951 Refugee Convention among Member States, inducing Courts to declare transfers as unlawful. ${ }^{567}$ Given that domestic and international courts are prepared to question the safety

562 J. Johnston, 'Dublin Convention', in UNHCR, 4th International Symposium on the Protection of Refugees in the Central European and Baltic States, 27-29 September 1998, Bled/Slovenia. Report and Proceedings (1999, UNHCR, Geneva), p. 51. This reflects another choice imposed by lengthy Dublin procedures, namely that between detention and defection. The legality of detention is subject to the narrow legal confinements of Article 5 (1) (f) ECHR. See G, Noll, 'Unsucessful Asylum Seekers-The Problem of Return', 37 International Migration 1 (1999), pp. 280-1.

${ }^{563}$ Dublin Working Paper, para. 22.

564 Dublin Working Paper, para. 38.

565 Ibid.

566 The Dublin Working Paper gives a detailed account of evidentiary problems in paras 42-5, enumerating the general lack of evidence, the incentives to destroy documents, and the problems experienced in situations where indicative evidence only is available.

567 Dublin Working Paper, para. 23. 


\section{CHAPTER 5}

of Member States ${ }^{568}$, it is somewhat surprising that UNHCR is apparently not: the Office has refrained from demanding that appeals against Dublin removals have suspensive effect. ${ }^{569}$

\section{Splitting of families}

As already noted, the family criterion is doubly confined through its limitation to recognised refugees and its very narrow concept of family. As UNHCR has rightly pointed out, the Dublin Convention can, at worst, lead to persistent family splitting. ${ }^{570}$ While the sovereignty clause and the humanitarian clause may mitigate this problem somewhat, their use is at the discretion of states. Apparently, there is no quick fix to this problem, as the Article 18-Committee has been unable to agree on a draft decision concerning the transfer of family members under both clauses. ${ }^{571}$ By conclusion, the Convention offers neither a legal obligation nor an

${ }^{568}$ Apart from the U.K. courts named in the Dublin Working Paper and in chapter 12.2 the ECtHR has affirmed its competence to scrutinise Dublin removal decisions with a view to their compliance with the ECHR: 'The Court finds that the indirect removal in this case to an intermediary country, which is also a Contracting State, does not affect the responsibility of the United Kingdom to ensure that the applicant is not, as a result of its decision to expel, exposed to treatment contrary to Article 3 of the Convention. Nor can the United Kingdom rely automatically in that context on the arrangements made in the Dublin Convention [...]. The Court has therefore examined below whether the United Kingdom have complied with their obligations to protect the applicant from the risk of torture and ill-treatment contrary to Article 3 of the Convention'. ECtHR, Decision as to the Admissibility of Application 43844/98, T.I. vs. the U.K., 7 March 2000, p.16.

${ }^{569} \mathrm{UNHCR}$ suggests that the applicant should be offered an opportunity to request a review of the decision on a Member State's responsibility, in so far as the applicant can forward further elements relevant to the application of the Dublin criteria and procedures in his or her particular case'. The limited scope of review in this demand stands out in marked contrast to the requirement that removal to non-Member States should entail a general appeal option with suspensive effect, set out in the same document (see note 613 below). UNHCR, Implementation of the Dublin Convention: Some UNHCR Observations (May 1998, Geneva).

570 UNHCR, Implementation of the Dublin Convention: Some UNHCR Observations (May 1998, Geneva). In its observations, UNHCR suggests that Member States use the humanitarian clause (Art. 9 DC) at least in cases where a family member is gravely ill, has a serious handicap, or is of old age, where one of the applicants is pregnant or has a newborn child, and where minors risk being separated and left unattended. Moreover, the Office calls for guidelines encouraging Member States to apply a broader notion of 'family' than has been laid down in Art. 4 DC.

${ }^{571}$ Dublin Working Paper, para. 32. 
incitement to preserve family unity. ${ }^{572}$ The Amsterdam Action Plan acknowledges this when it spells out that a study 'should be undertaken to see to what extent the [Dublin, GN] mechanism should be supplemented inter alia by provisions enabling the responsibility for dealing with the members of the same family to be conferred upon one Member State where the application of the responsibility criteria would involve a number of States $[\ldots]{ }^{573}$

\section{Inequitable distribution of asylum seekers among Member States}

'The Convention', states the European Commission, 'has been criticised in some quarters on the grounds that it puts too great a burden on Member States which have external borders which are particularly exposed to migratory pressures'. ${ }^{574}$ The Commission goes on to state that 'the number of transfers is relatively modest', concluding that, 'at present, the system can not be said to be putting an excessive burden on any Member State' ${ }^{575}$ In a later chapter, we shall look into this critique at greater length, pursue a closer analysis of the statistical material available and contest the moderate conclusion of the Commission. ${ }^{576}$

Concluding on the aggregated critique, the European Commission finally states in its Dublin Working Paper that there 'do not appear to be many viable alternatives' to the Convention. ${ }^{577}$ It is noteworthy, though, that two NGOs have launched a proposal for a draft directive replacing the Dublin Convention, which allocates responsibility to the Member State where an application was first filed, allowing for a number of exceptions (family reunion, or close links to another Member State). ${ }^{578}$ Accepting this proposal would imply admitting the complete defeat of the Dublin project. Thus, it seems fair to assume that a new Community instrument will refrain from developing an approach radically different from the existing Convention, and that causing the presence of an asylum

\footnotetext{
572 This is also confirmed in paras 32-4 of the Dublin Working Paper.

573 Ibid.

${ }^{574}$ Dublin Working Paper, para. 35.

575 Ibid.

${ }^{576}$ See chapter 8.4.1 below.

577 Dublin Working Paper, para. 59.

578 ILPA/MPG and S. Peers, The Amsterdam Proposals. The ILPA/MPG Proposed Directives on Immigration and Asylum (2000, ILPA/MPG, London, Brussels), pp. 58-9.
} 


\section{CHAPTER 5}

seeker on the territory of a Member State will continue to entail responsibility for processing her claim.

\subsubsection{Complementing Dublin: The Eurodac Proposal}

In March 1996, Member States began negotiations on a Convention to establish an identification system based on the fingerprints of asylum seekers. The so-called Eurodac system ${ }^{579}$ would gather fingerprint data collected by Member States and transmit it to a Cerrtral Unit, which would compare individual sets of fingerprints to the data retained in the system at the request of a Member State. In addition, Member States also prepared a draft Protocol, which was intended to further facilitate the application of the Dublin Convention by providing for the collection of fingerprint data relating to persons apprehended in connection with the irregular crossing of an external border. This data would be available for the purposes of comparison with the fingerprints of people who subsequently claimed asylum in one of the Member States. In addition, the Protocol provided a facility for checking with Eurodac in certain circumstances to determine whether a person found illegally within a Member State had previously claimed asylum in another Member State. The text of a draft Convention and a draft Protocol under Title VI of the Treaty on European Union was prepared and consensus was reached within the Council in March 1999 to freeze the text pending the entry into force of the Treaty of Amsterdam. ${ }^{50}$

After the entry into force of the latter, the Eurodac systems falls under EC competence by virtue of Article 63 (1) (a) TEC. On the basis of the frozen texts, the Commission presented a proposal in 1999 aiming at the adoption of a binding and directly effective Eurodac Regulation. ${ }^{581}$ The legal form of a regulation was chosen, as the technical nature of Eurodac makes uniform implementation of the system necessary.

579 For a brief overview, see M. Toussaint, 'Eurodac: un système informatisé européen de comparaison des empreintes digitales des demandeurs d'asile, Revue du marché commun et de l'union européenne 429 (1999).

580 Explanatory Memorandum to the Draft Eurodac Regulation, para. 1.2.

581 European Commission, Proposal for a Council Regulation (EC) concerning the establishment of 'Eurodac' for the comparison of the fingerprints of applicants for asylum and certain other aliens, 1999/05/26, COM/99/0260 final-CNS 99/0116 [hereinafter Draft Eurodac Regulation]. 
The draft Eurodac Regulation covers three groups of persons: asylum seekers ${ }^{52}$, persons apprehended in connection with the irregular crossing of an external border ${ }^{583}$, and persons found illegally present within a Member State ${ }^{584}$. Taking fingerprints from asylum seekers allows for tracking multiple applications and thus offers considerable advantages for the application of the Dublin criteria. By way of example, fingerprinting persons apprehended at external borders facilitates the application of Article 6 DC, linking illegal border crossing to responsibility under the Dublin Convention. Furthermore, fingerprinting persons found illegally present within Member States facilitates the application of Article 10 (1) paras (c) and (e) DC, relating to the obligation to readmit or take back applicants, incumbent on the responsible state.

Upon adoption, Eurodac will have considerable impact on the situation of protection seekers. Circumvention of the Dublin criteria by using multiple identities or by manipulating the travel itinerary will become much more difficult. Inhibiting manipulation may be considered a good thing. It presupposes, however, that the protection offer in various Member States is more or less of the same standard, and that no protection lacunae exist in any of the Member States. While this is not the case, any perfection of the Dublin Convention will modify, rather than solve, the problems attached to its application.

\subsubsection{Allocation to Non-Member States}

\subsubsection{The 1992 Resolution on Host Third Countries}

Allocation between Member States and third countries is addressed in a non-binding resolution on the safe third country concept:

O EC Ministers Resolution of 30 November-1 December 1992 on a Harmonized Approach to Questions Concerning Host Third Countries $^{585}$

\footnotetext{
582 Arts 4-7 Draft Eurodac Regulation.

583 Arts 8-10 Draft Eurodac Regulation.

584 Art. 11 Draft Eurodac Regulation.

585 WGI 1283 [hereinafter STC Resolution].
} 


\section{CHAPTER 5}

The STC Resolution sets out a number of non-binding norms on the procedural aspects of the safe third country-concept, including its relationship to the Dublin Convention, and the qualification of third states as safe.

The procedural rules position the safe third country concept-or, in the original language of the resolution, the concept of 'host third countries'in the asylum procedures conducted by Member States. The overarching interest is one of procedural economy, expressing itself in the following five principles:

(a) The formal identification of a host third country in principle precedes the substantive examination of the application for asylum and its justification;

(b) The principle of the host third country is to be applied to all applicants for asylum, irrespective of whether or not they may be regarded as refugees;

(c) Thus, if there is a host third country, the application for refugee status may not be examined and the asylum applicant may be sent to that country;

(d) If the asylum applicant cannot in practice be sent to a host third country, the provisions of the Dublin Convention will apply;

(e) Any Member State retains the right, for humanitarian reasons, not to remove the asylum applicant to a host third country. ${ }^{586}$

Principle (a) introduces a split into formal and substantive procedures. By this step, a doubling of substantial assessment is avoided. The referring state limits its assessment to formal aspects, where referral to a safe third country or a responsible Member State can take place. Substantial assessment is catered for by the receiving state. The hierarchy of referral introduced in Article 3 (5) DC is reiterated in principle (d), and a sovereignty clause reminiscent of Article 3 (4) DC is laid down in principle (e).

${ }_{586}$ Art. 1 STC Resolution. 
Article 2 of the STC Resolution enshrines the criteria for the qualification of a third country as safe:

Fulfilment of all the following fundamental requirements determines a host third country and should be assessed by the Member State in each individual case:

(a) In those third countries, the life or freedom of the asylum applicant must not be threatened, within the meaning of Article 33 of the Geneva Convention.

(b) The asylum applicant must not be exposed to torture or inhuman or degrading treatment in the third country.

(c) It must either be the case that the asylum applicant has already been granted protection in the third country or has had an opportunity, at the border or within the territory of the third country, to make contact with that country's authorities in order to seek their protection, before approaching the Member State in which he is applying for asylum, or that there is clear evidence of his admissibility to a third country.

(d) The asylum applicant must be afforded effective protection in the host third country against refoulement, within the meaning of the Geneva Convention. [...]

Thi: article is problematic in that it focuses solely on extraterritorial protection under the 1951 Refugee Convention. Other explicit or implicit prohibitions of refoulement ${ }^{587}$ are simply not taken into account, although they may offer wider protection in some cases than the prohibition of refoulement under the 1951 Refugee Convention. The criterion offered by paragraph (b) does not cover such forms of extraterritorial protection, as it is limited to mistreatment taking place in the third country. Given the wide scope of the instrument's application, as spelt out in Article 1 (b), this omission is of concern. Moreover, the criteria set out in the present article focus solely on negative state obligations, oblivious of the importance of positive obligations for extraterritorial protection worth its name. ${ }^{588}$

${ }^{587}$ See chapters 9.1.2 and 9.1.4 below.

${ }^{588}$ Noll and Vedsted-Hansen, 1999, p. 396 with further references in note 122. 


\section{CHAPTER 5}

Article 3 of the STC Resolution sets out the relationship between the Dublin Convention and the allocation to a safe third country:

(a) The Member State in which the application for asylum has been lodged will examine whether or not the principle of the host third country can be applied. If that State decides to apply the principle, it will set in train the procedures necessary for sending the asylum applicant to the host third country before considering whether or not to transfer responsibility for examining the application for asylum to another Member State pursuant to the Dublin Convention.

(b) A Member State may not decline responsibility for examining an application for asylum, pursuant to the Dublin Convention, by claiming that the requesting Member State should have returned the applicant to a host third country.

(c) Notwithstanding the above, the Member State responsible for examining the application will retain the right, pursuant to its national laws, to send an applicant for asylum to the host third country.

(d) The above provisions do not prejudice the application of Article 3(4) and Article 9 of the Dublin Convention by the Member State in which the application for asylum has been lodged.

It is made clear that allocation to a safe third country remains a facultative measure, and refraining from it does not entail any consequences for the application of the Dublin Convention. However, it is pointed out in paragraph (c) that allocation among Member States does not preclude subsequent allocation to a safe third country outside the EU.

The STC Resolution has been criticised on a number of counts. On the procedural side, some authors have taken the position that removal of a protection seeker to a Non-Member State without a substantial examination of her claim would contravene the 1951 Refugee Convention. ${ }^{589}$ Moreover, they have pointed out that the STC Resolution falls back behind the standards set in EXCOM Conclusions. ${ }^{590}$ Somewhat

589 Standing Committee of experts in international immigration, refugee and criminal law, Commentary on the Draft Conclusions of the European Ministers responsible for Immigration Affairs meeting in London on 20.11.1992 and the not yet adopted Resolution concerning Family Reunification (1993, Forum, Utrecht), p. 16.

590 Ibid., p. 17. 
more cautiously, UNHCR has underscored that decisions on removal to host third countries should only be made by the authority normally competent in asylum matters, that the consent of the host third country should be sought before removal, that protection seekers should not be returned to countries where they have been in mere transit and that the availability of treatment according to basic human standards should be taken into account when determining the status of a third country as safe. ${ }^{591}$

\subsubsection{Complementing Allocation to Non-Member States: Readmission Agreements}

During the nineties, readmission agreements were concluded at an amazing pace both in and outside Europe, leaving a profound mark on the system of extraterritorial protection. ${ }^{592}$ What is a readmission agreement, and what role does it play in the return of protection seekers to safe third countries? ${ }^{593}$ The Report on the Implementation of Readmission Agreements elaborated by the Working Group of the Budapest Group contains a working definition of what constitutes a readmission agreement:

A readmission agreement shall be understood in general as an international agreement stipulating the procedures for the return and readmission of individuals (with the exception of extradition). The objective of such an agreement [...] is to:

591 UNHCR, Resolution on a Harmonized Approach to Questions concerning Host Third Countries. UNHCR Position, December 1992, paras 1-5.

592 The number of readmission agreements involving European states is large, but difficult to specify, as many agreements remain unpublished or are published with a considerable delay. The IGCARMP maintains a non-public directory of agreements, which is available to participating states only. It has been suggested that, since the late 1980 s, some 220 bilateral readmission agreements have been concluded world-wide. IGCARMP, IGC Report on Readmission Agreements (1999, IGCARMP, Geneva), p. 4.

${ }^{593}$ For a typology of readmission agreements and an overview of the technical solutions used by states see Noll, 1997, pp. 416-24. For the perspective of industrialised goal states, see IGCARMP, 1999. 


\section{CHAPTER 5}

- combat illegal migration (and in this sense to maintain public order and political stability in the countries affected by the immigration influx)

- share the burden of illegal migration by more countries

- have a preventive influence on the thinking of potential immigrants

and thus to meet one of the conditions for the gradual reduction or abolition of the control on the internal borders of the countries which follow the readmission principles. ${ }^{594}$

This definition stretches over readmission agreements in general. While some agreements exclusively cover nationals of the State Parties, others are applicable to nationals of third countries as well. The rationale for concluding the former type of readmission agreements is to facilitate return of nationals of the receiving state illegally present in the sending state. This type of agreement shall be looked into in a later section dealing with return issues. ${ }^{595}$ Readmission agreements of the latter type (also covering third-country nationals), however, have a wider ambit. With respect to third-country nationals, such agreements represent a cooperation between a transit country and a destination country. Returning third country nationals to a country other than the country of nationality or habitual residence presupposes some form of agreement between the two states. ${ }^{596}$ Therefore, a readmission agreement of the latter type is a precondition for return to safe third countries. In the present context, we need only deal with such agreements.

Due to the absence of provisions guaranteeing the observance of the prohibition of refoulement, UNHCR has expressly discouraged the use of 'classical bilateral readmission agreements [...] to return asylum-seekers, even where this is technically possible' ${ }^{597}$ Nonetheless, this has had little impact on the determination of Member States to make continued use of

\footnotetext{
594 Working Group of the Budapest Group, Report on the Implementation of Readmission Agreements, Doc. No. BG11/96 C, p. 2.

595 See chapter 7.2 below.

596 See chapter 7.2.1 below.

597 UNHCR Division of International Protection, Note for the Standing Committee of the Executive Committee, Composite Flows and the Relationship to Refugee Outflows, EC/48/SC/CRP.29, 25 May 1998, para. 19.
} 
readmission agreements to remove protection seekers to third countries deemed safe.

\subsection{The EU acquis on Readmission}

Presently, the EU acquis comprises three instruments relating to the readmission of third-country nationals to transit countries. In 1994, the Council drew up a specimen agreement, covering the readmission of both nationals and third-country nationals, and recommended its use in a nonbinding instrument:

- Recommendation of 30 November 1994 concerning a specimen bilateral readmission agreement between a Member State of the European Union and a third country ${ }^{598}$

The specimen agreement was designed to serve as a model to be used flexibly by Member States when negotiating agreements with nonMember States.

A year later, the specimen agreement was followed by guiding principles for drawing up readmission protocols. Readmission protocols are typically concluded simultaneously with readmission agreements. While the agreement regulates the scope and content of the obligation to readmit in a general fashion, the protocol sets out detailed procedural rules to be followed by the authorities seized with readmission. The guiding principles were laid down in the

- Recommendation of 24 July 1995 on the guiding principles to be followed in drawing up protocols on the implementation of readmission agreements. ${ }^{599}$

In 1996, the Council took further steps to disseminate readmission obligations covering both nationals and third-country nationals by adopting the

${ }^{598}$ OJ (1996) C 274, pp. 20-4 [hereinafter EU specimen agreement]. While earlier drafts of the specimen contained substantial provisions safeguarding rights and interests of protection seekers, those are lamentably absent in the finalised text. See Guild and Niessen, 1996, p. 407.

599 OJ (1996) C 274/25. 


\section{CHAPTER 5}

O Council Conclusions of 4 March 1996 concerning readmission clauses to be inserted in future mixed agreements. ${ }^{600}$

Following this instrument, when mixed agreements between the Member States of the EU and third states are negotiated in the future, it shall be considered whether to include an option to future readmission agreements. By virtue of such a clause, the contracting third state would be obliged to conclude a bilateral agreement on the readmission of third country nationals with Member States which so request. This is the first tangible expression of the Council's wish to exploit the accumulated bargaining power of the Fifteen to facilitate the conclusion of readmission agreements with non-Member States.

None of the three instruments adopted in the area are legally binding. In practice, the scope and content of bilateral readmission agreements concluded by Member States and third states continue to vary to a considerable extent. ${ }^{601}$

\subsection{Competencies after Amsterdam}

After the entry into force of the Amsterdam Treaty, the conclusion of readmission agreements touches upon the competencies of the EC. Article 63 (3) (b) TEC prescribes that the Council shall adopt, within the transitional period of five years, measures on illegal immigration and illegal residence, including repatriation of illegal residents. Article 63 TEC also states explicitly that such measures adopted by the Council shall not prevent any Member State from maintaining or introducing in the areas concerned national provisions which are compatible with this Treaty and with international agreements.

This raises the question to what extent the Council, all Member States, or single Member States may still conclude readmission agreements without infringing upon EC competencies. The Legal Service of the

600 Docs No. 4272/96 ASIM 6 and 5457/96 ASIM 37.

601 Even within one and the same country, important variations in the chosen solutions may occur. Germany is a case in point. For an overview, see G. Lehnguth, H. Maaßen and M. Schieffer, Rückfübrung und Rückübernabme. Die Rückübernabmeabkommen der Bundesrepublik Deutschland (1998, R.S. Schulz, Starnberg). 
Council has attempted to clarify this issue, and its reasoning shall be briefly reflected in the following. ${ }^{602}$

According to the constant case law of the European Court of Justice, an instrument adopted within the Council or by all Member States acting outside the Council may not encroach upon the powers of the EC. Therefore, after the entry into force of the Treaty of Amsterdam, the Council or all Member States jointly may no longer conclude such agreements. ${ }^{603}$

Whether or not the conclusion of readmission agreements by a single Member State with a third country would violate the EC Treaty hinges on two factors.

First the Council and, if necessary, the Court of Justice has to assess whether readmission agreements are inseparably bound up with the achievement of the Community's immigration policy objectives. If this is the case, it should not be possible for one or more Member States alone to continue to conclude such agreements with third countries, on account of the potential resulting distortions for other Member States in the context of an area without internal border controls. This factor is largely considered to be a matter for the Council's political judgement. ${ }^{604}$

Second, it has to be verified whether or not there are any internal Community rules on repatriation which might be affected by the conclusion of such an agreement. To wit, such rules do not exist to date, apart from Article 23 SC. According to the Council's Legal Service, this provision is not incompatible with the conclusion of a readmission agreement by one or more Member States and a third country. ${ }^{605}$

Interestingly, the first factor takes into account that the removal of third country nationals possesses a dimension of solidarity. It would be unfair if single Member States secured readmission by swiftly concluding bilateral readmissiun agreements with third countries, thereby exploiting their own political or economical leverage at the cost of other, less influential Member States.

\footnotetext{
${ }^{602}$ The following presentation is based on an article in Migration News Sheet. With the Amsterdam Treaty Now in Force, Member States May Not Collectively Conclude ReAdmission Agreements With Third Countries, Migration News Sheet, June 1999, p. 1.

${ }^{603}$ Ibid.

${ }^{604}$ Ibid.

${ }^{605}$ Ibid.
} 


\section{CHAPTER 5}

In later 1999, and reacting on the effects of the Amsterdam Treaty, the Council adapted its earlier position taken on readmission clauses in mixed agreements by means of the following instrument:

- Conséquences de l'entrée en vigueur du traité d'Amsterdam sur les clauses de réadmission dans les accords communautaires et dans les accords entre la Communauté européenne, ses Etats membres et des pays tiers (accords mixtes)-Adoption d'une décision du Conseil ${ }^{606}$.

This decision contains specific specimen readmission clauses, which are to be inserted in future community agreements and mixed agreements. The scope of these clauses is indeed the widest possible. ${ }^{607}$ First, a reciprocal obligation to readmit nationals and to issue identification documents for that purpose is included. Second, the contracting parties (that is, the Community and a third state) oblige themselves to conclude a agreement upon request, which would contain specific readmission obligations, including the duty to readmit third-country nationals or stateless persons. Third, until such an agreement has been concluded, the third state obliges itself to conclude bilateral agreements with single Member States upon request, which would, again, regulate specific readmission obligations, including a duty to readmit third-country nationals or stateless persons. Thus, the instrument makes clear that bilateral arrangements are provisional, and will cease to apply when a Community agreement or a mixed agreement enters into force.

While the specimen clauses primarily target undocumented migrants and rejected protection-seekers, they could also be used to return protection seekers with pending claims to third countries considered as safe. However, it is reasonable to expect considerable resistance by third states against the octroi of readmission obligations vis-à-vis non-nationals. On the other hand, the accumulated bargaining power of the Fifteen is considerable.

606 Adopted on 2 December 1999. Neither an English-language version, nor the document number was available at the time of writing.

607 Ibid, Annex, Arts A-D. 


\subsubsection{Conclusion}

Certain aspects of the EU acquis related to allocation give rise to concern.

Firstly, it has been noted that states employ different concepts of what constitutes a safe third country. Within the EU, disparities in the understanding and the application of the concept have been documented in a survey prepared by the Council. ${ }^{608}$ In Central and Eastern European countries, the prime partners for readmission at present, the concept is interpreted in very different manners by states applying it. ${ }^{609}$ This means that it is virtually impossible for the first requesting state to predict where the requested state may return a given protection seeker to a further (fourth) state. She might be sent on to a country that would not have been considered safe by the state starting the return movement. The risk of chain refoulement is systemically aggravated ${ }^{610}$, and cases of actual refoulement have been reported. ${ }^{611}$ It has been observed with justified concern that ' $[t]$ exts of readmission agreements-even the model readmission agreement drawn up by the EU-fail to specify guaranteed access to status determination procedures, nor do they reiterate the obligation of nonrefoulement'. ${ }^{612}$

Secondly, the lack of communication between requesting and requested state might put the legal certainty of protection seekers at stake. If it is not made clear to the authorities of the requested state that a returned person made a protection claim which has not been decided in substance, the risk prevails that such a case will be treated simply as an

${ }^{608}$ Council of the European Union, Monitoring the implementation of instruments adopted concerning asylum-Summary report of the Member States' replies to the questionnaire launched in 1997, 17 July 1998, Doc. No. 8886/98 ASIM 139 [hereinafter 1998 Council Survey], pp. 23-30. By way of example, not all Member States have laid down the criteria enumerated in para. 2 STC Resolution in their domestic legislation. Furthermore, the concept of safe third countries is applied to situations of 'mere transit' in five Member States, while eight Member States refrain from doing so.

${ }^{609}$ For an overview of state practice in Central and Eastern Europe, see F. Liebaut, Liebaut, Legal and Social Conditions of Refugees and Asylum Seekers in Central and Eastern Europe (1999, Danish Refugee Council, Copenhagen).

${ }^{610}$ See A. Achermann and M. Gattiker, 'Safe Third Countries: European Developments', 7 IJRL 19 (1995).

611 In a 1995 study, ECRE compiled 16 cases of chain refoulement in 1994. ECRE, Safe Third Countries'. Myth and Realities (1995, London), Appendix B.

${ }^{612}$ Landgren, 1999 , p. 29, referring to the EU specimen agreement. 


\section{CHAPTER 5}

illegal migrant which can be returned to the country of origin. ${ }^{613}$ Readmission agreements usually do not address this need for communication. Although a non-binding EU instrument demands that ' $[t]$ he third country authorities must, where necessary, be informed that the asylum application was not examined as to substance ${ }^{614}$, state practice in the EU diverges widely on this important issue. ${ }^{615}$ In this respect, removal among Member States under the Dublin Convention offers an advantage: it is clear from the outset that the claimant thus removed has not enjoyed a substantial determination of her claim.

Thirdly, allocation to another Member State or a safe third country may deteriorate the legal standing of the protection seeker. Within the $\mathrm{EU}$, asylum and aliens legislation still varies considerably, and allocation to a Member State with a restrictive practice can greatly diminish the chances of being protected. Allocation to a safe third country outside the Union may result in even greater protection losses. This is due to a more limited protection offer and a restrictive recognition practice. In general, Western European countries offer various forms of subsidiary protection

${ }^{613}$ Therefore, UNHCR has suggested that the consent of the receiving country be obtained before a protection seeker is sent to that country, and that it 'be informed in advance of the return of any asylum-seeker whose application has not yet been substantively examined so that appropriate notification can be given to the border officials and the necessary protection guaranteed'. UNHCR, Readmission Agreements, 'Protection Elsewhere' and Asylum Policy, August 1994, para. 5. With regard to the Dublin Convention, UNHCR has demanded that transfers to non-Member States under Art. 3 (5) DC should be goverened by specific guidelines, ensuring that the sending state seeks the consent of the receiving state '(i) to readmit the asylum seeker; (ii) to consider the merits of the claim; and (iii) to provide effective protection as long as required'. Moreover, the sending state should inform the receiving country in writing that no decision of the substance of the claim has taken place, and that the applicant should receive an opportunity to request review of the removal decision, including suspensive effect. UNHCR, Implementation of the Dublin Convention: Some UNHCR Observations, May 1998. One may wish to add that there are good reasons to demand that these guidelines should also govern transfers between Member States (given that Art. 3 (5) entails the risk of transfer to a fourth country outside the Union). However, UNHCR has refrained from this demand, giving the impression that the Office applies double standards.

${ }^{614}$ EU Council Resolution on minimum guarantees for Asylum Procedures, 20 June 1995, Doc. No. 5585/95, para. 22, OJ (1996) C 274/13.

${ }^{615}$ Five Member States inform the third country concerned, although only one does operate a procedure based on written reports. Other Member States do not inform the country concerned. See 1998 Council Survey, p. 30. 
in domestic law. ${ }^{616}$ In Central and Eastern European states, the protection offer is largely limited to the Convention refugee category ${ }^{617}$ Moreover, recognition rates in the Central and Eastern European Countries are generally lower than in the EU. ${ }^{618}$ Thus, reallocation to Eastern neighbours implies a considerable deterioration of protection prospects for the average claimant.

Finally, as the discussion on Eurodac, evidence and time limits has shown, allocation mechanisms are open to manipulation by the individuals subjected to them. It is conceivable that some protection seekers prefer continued illegality in the destination country to being allocated to a safe third country. While they might vanish from the asylum statistics of the destination state, they do not necessarily vanish from its territory. Rather than solving the problem, control measures merely shift it to another arena.

\footnotetext{
${ }^{616}$ An overview of diverging practices in Member States is given in European Council, Summary of replies concerning the national instruments of protection falling outside the scope of the Geneva Convention-Subsidiary protection, 6 January 1998, Doc. No. 13667/97 ASIM 267.

${ }^{617}$ For an overview, see F. Liebaut, Legal and Social Conditions of Refugees and Asylum Seekers in Central and Eastern Europe (1999, Danish Refugee Council, Copenhagen).

${ }^{618}$ See chapter 8.4.2 below.
} 